\title{
Ecologies of Hope: environment, technology and habitation - case studies from the intervenient middle
}

\author{
S. Ravi Rajan and Colin A.M. Duncan ${ }^{1}$ \\ University of California, Santa Cruz, USA \\ Queen's University, Canada
}

\section{Introduction}

The world is rife with a million mutinies now. ${ }^{2}$ Seemingly everywhere are protests against dams and nuclear power plants; 'occupy' movements against large financial institutions and Wall Street; and coordinated campaigns against governments, corporations, and the World Bank. These spectacles are often big, vocal, and visible (Benítez 2011; Castells 1985; Danaher 1994; Della Porta and Diani 2006; O'Brien 2000; Rich 1994). They make the news. They also gain scholarly attention. Practitioners of the discipline of political ecology have produced tens of dissertations on various environmental struggles from around the world, and on the discourses that legitimate development theory and practice (Peet and Watts 2004). Scholars in Science and Technology Studies (STS) have similarly analyzed the entanglements between knowledge and power; explored the cultural underpinnings of environmental analytical and mitigation systems; and argued for democracy and accountability (Cozzens and Woodhouse 1995; Hackett et al. 2008).

Yet, for millions of people around the world, there are issues more immediate, more urgent, than addressing political economic equity or designing some new social or technological utopia. What is critical to them is ensuring that they have niches for day-to-day survival. These may take the form of 'appropriate technologies' such as small dams that help irrigate their farmlands. They can also take the form of an organizational structure that yields them slightly better prices for their produce. They might consist of viable land reforms that enable them to eke out livelihoods from farming. They could assume the shape of a design that produces more convivial spaces for how they live, work, and commute. Or indeed, they can be about landscapes and infrastructures that bridge livelihoods and ecological limitations. Some of these niches occur in highly localized contexts, such as a village or a farm. Others are collaborations between 'local' people and globally networked agents; or between the formally educated and those who are not, such as, for example, between engineers and laypeople.

Such entities and interactions are the subject of this special issue. The cases discussed herein attempt to create spaces for bettering human lives and livelihoods. Arguably, with some specific exceptions, they do not make much of a dent on the wider political economic equations that, reworked, might define a just world (Harvey 1996). They are not new social movements or novel forms of resistance, or even examples of popular protest and mobilization against bio-power in any form (Escobar 1984; Habermas 1981; O'Brien 2000; Rabinow and Rose 2006; Wignaraja 1993). Neither are they examples of frontiers of a new socially engaged capitalism, exemplified by the mantra of fortune at the bottom of the pyramid (Prahalad 2010). They are what they are - discrete, specific, and often, local. Needless to say, it is perfectly possible to dismiss such cases as historically uninteresting, because they are less likely to produce large-scale change. Indeed, in the history of Marxism, interventions of the kinds discussed in this volume were dismissed as "reformist," and criticized as being counter-revolutionary (Gorz 1968).

We disagree with all such reductive and/or condescending acts of labelling as just so much intellectualist baggage. Adopting what might seem to be an overly crass and pragmatic perspective, it appears indeed that for millions of people and hundreds of ecosystems, discrete initiatives to ensure their survival are the only 'revolutions' that will ever happen - at least in their lifetimes. Such initiatives, and the motivations that underlie them, cannot therefore be understood only with recourse to an analytical framework about resistance to big power, technology, state or capital. We argue that in order to be historically significant, social change need not just be about large, transformational events recognizable as revolutionary, but can equally be about relatively localized everyday attempts to marginally improve the day-to-day drudgery of life. The cases such as we report on here can, in effect, be understood as attempts at creating habitation "in the middle."

\footnotetext{
${ }^{1}$ S.Ravi Rajan, Associate Professor, Environmental Studies, University of California, Santa Cruz, CA 95064, USA. Colin A.M. Duncan, Adjunct Associate Professor, Department of History, Queen's University, Kingston, Ontario K7L 3N6, Canada and Adjunct, History and Classical Studies, McGill University, Canada. Emails: Ravi Rajan srrajan "at" ucsc.edu and colin.duncan "at" queensu.ca. This is the Introduction to Rajan S.R. and Duncan C.A.M. (eds.) "Ecologies of Hope", special issue of Journal of Political Ecology 20: 70-179. We are greatly indebted to the National Science Foundation and the School of Advanced Research in the Human Experience (SAR), both in the USA, who gave us a Small Workshop grant that brought the contributors together. We are extremely grateful to Dr. Simon Batterbury for his editorial insights, and the time and effort he expended in working individually with the various contributors of this special issue, and to Costanza Rampini for her editorial assistance. Any remaining errors are ours.
}

${ }^{2}$ This phrase is adapted from a book by VS Naipaul that bears this title (see Naipaul 1990). 
We use the term "middle" deliberately, and do so with reference to three senses of the term. Firstly, we invoke G. W. Hoskin's term "middle peasants" to describe solid conventional householders, the hearts and souls of their communities (Hoskins 1953; Hoskins 1957; Hoskins and Stamp 1963; Hoskins 1964; Hoskins 1969; Hoskins 1976). For us, the five cases in this collection, and the wider trends they represent, are movements driven by the souls of communities (though in our case, not always rural), acting in the best interests of their groups, but in doing so, producing spaces and niches, or ecologies of hope, that have appeal and resonance beyond the local. Second, we use the term 'middle' as representing spaces between the individual (whether as consumer or protester), and larger formations, such as the state, or technological constellations, or big capital. Thirdly, we use the term 'middle' to mark the terrain that is inbetween social and economic status quo and revolution.

The purpose of this collection is deliberately to ignore the big events, the bookends of history, as it were, and to look carefully at the "middle;" at what lies between the bookends. By definition, exploring the "middle" implies examining the local and the contextual, as well as considering culturally and temporally bound episodes. Nevertheless, our thesis is that the seemingly disparate can add up to something broader or more universal - and, in the process, tell us something about humanity's relations with itself and the rest of nature; about potential sources of emancipation and livelihood; and about the best uses of freedom. The purpose of this special issue, then, is to use a few carefully constructed case studies from around the world to examine the ecologies of hope, the complex web of interconnected events and processes, structures and agents - humanity and nature in action - to help deepen and broaden our understanding of change and agency.

\section{Drawing upon Karl Polanyi}

Our analytical approach draws upon the work of Karl Polanyi (Polanyi 1935; Polanyi 1947; Polanyi 1957a,b,c; Polanyi et al. 1957; Polanyi 1968; Polanyi 2005). We are, in particular, inspired by three of his key concepts. The first of these might be described as the distinction between formal and substantive economies. Invoking Aristotele's Nichomechian Ethics (Aristotle 1999), Polanyi held that "economies" can be conceived of in either of two ways (Polanyi 1957c). They can be built upon the "formalist" idea that social decision-making is principally an optimization problem of rational choice, given limited scarce means. Choice and action, according to the orthodox economic perspective that Polanyi called formalist economic systems, are institutionalized in markets, and are quantifiable via price mechanisms, regardless of whether the commodity in question is land, labor, or any other dimension of production. Polanyi rejected this conception of human economic motivations, stating that "To narrow the sphere of the genus economic specifically to market phenomena is to eliminate the greatest part of man's history from the scene" (Polanyi and Pearson 1977). What he meant was that markets in human history have served a wide range of economic and social functions, and not just those considered by neo-classical economists. He argued that the economy was constituted by more activities than exchange and markets. He also argued that, considered historically, the idea that markets can be understood merely by the concepts of scarcity or choice, is palpably incorrect.

In developing his preferred alternative "substantivist" approach, Polanyi drew upon cultural economic anthropology, and argued that livelihood strategies often involve adaptation to environment and material conditions, a process which may or may not involve the optimization problem because not all cultures care(d) to regard all things as commensurable along a single value spectrum (a necessary assumption for any calculation as such). On the contrary, he argued, many societies, past and present, specifically valued and institutionalized systems of reciprocity, mutuality, redistribution, and gift, wherein value propositions were fungible, and rooted explicitly in human social relations. Put differently, in substantive economics, human economic activities are recognized as embedded in institutions, which are economic and cultural. Polanyi also defined substantive economies as being based on actual, material interactions between humanity and its environment, as opposed to mere models of purported rational choice (Polanyi 1947; Polanyi 1957a; Polanyi 1957b; Polanyi 1957c; Polanyi et al.1957).

The second, and related, Polanyian idea that we draw upon is that of the modern disembedding of the economy and the environment from the their societal and cultural context (Beckert 2007). Polanyi argued that this (recurring) phenomenon caused, and tends to cause, widespread devastation for persons and households, leaving society as a whole and the environment exposed and without protection. The destruction is the performative work of a "theory" about political economy that long ago started to extoll such disembedding by another name: the "self-regulation" of integrated price-setting markets for almost all commodities. Polanyi was unusually interested in the alienation of humanity from the rest of nature by institutions that sought to impose formalist economic systems upon public resources. He wrote: "What we call land is an element of nature inextricably interwoven with man's institutions. To isolate it and form a market out of it was perhaps the weirdest of all undertakings of our ancestors" (Polanyi 1957a: 178). Polanyi argued that the economic function of land is just one of its many vital purposes for human communities. So making land into a "fictitious commodity", subjected to the laws of a market, let alone a market system, constitutes a running threat to the very cultural bases of human existence. Again, he stated, "Land is part of nature. The economic function of land is just one of the many vital purposes land has for human communities. To make land into a 
fictitious commodity and subject it to the laws of the real estate market threatens to shatter the cultural bases of human existence" (Polanyi 1957a: 178). Looking beyond the European focus he noted that "The impact of the commodification of land was seen most clearly in the European colonies. We saw there a brief, dramatic presentation of what happened in Europe over a longer period of time: the social and cultural system of native life had to be shattered" (Polanyi 1957a:178).

Our third critical point of departure is Polanyi's idea of the "double movement" (Birchfield 1999; Gill 1995; Hettne 1997; Silver and Arrighi 2003). Polanyi contrasted "blind economic improvement", on the one hand, and "habitation," on the other. The latter is an attempt by society to "protect itself against the forces that undermine its social solidarity and threaten to distort its relationship to the natural environment" (Polanyi 1957a: 132). In essence, Polanyi argued that processes that result in a loss of cultural "habitation" engender movements by societies to protect themselves, and that this can happen at many levels. His collective term for the dialectic of threat and protection may be his most distinctive theoretical concept. Writing about the tensions unleashed in the Nineteenth Century he wrote:

The double movement can be personified as the action of two organizing principles in society, each of them setting itself specific institutional aims, having the support of definite social forces and using its own distinctive methods. The one is the principle of economic liberalism, aiming at the establishment of a self regulating market, relying on the support of the trading classes, and using largely laissez-faire and free trade as its method; the other is the principle of social protection aiming at the conservation of man and nature as well as productive organizations, relying on the varying support of those most immediately affected by the deleterious action of the market - primarily, but not exclusively, the working and the landed classes - and using protective legislation, restrictive associations, and other instruments of intervention as its methods (Polanyi 1957a:132).

Polanyi started to publish his major ideas during World War Two. His overall purpose was to argue not just that social experimentation must be democratic, but that it must be historically self-conscious to be effectively democratic. Cultural self-consciousness is what he meant, not individuated self-consciousness. Democracy presupposes discussion, and discussion presupposes some shared, albeit constructed historical consciousness about situations requiring attention. So importantly and comprehensively did classic economistic liberals and leftists miss this key point that Polanyi turned in exasperation to anthropology after the war to try to make a case in support of his argument from another angle altogether, in order to foil all detractors past and future, right and left.

Polanyi's distinctive analytic claim was that there can be no hope for positive social change that does not begin with the realization that culture is really what humans live in; and that mechanical models of society, whether intended for good or ill, are bound to do harm to the extent they push cultural change beyond rates compatible with daily life, with normal comprehension and habits. In the Nineteenth Century, the English had embarked simultaneously on two gigantic social experiments. One was an accelerating shift to machine production of ordinary commodities (powered mostly by coal, a point Polanyi did not stress as much as we now should) (Clark and Foster 2001; Jevons 1906). The other was an increasingly dogmatic resort to an integrated system of markets to set the prices for all commodities, including the factors of their production (Skidelsky 2003). Since these latter: land, labour power, and money, in fact were not and cannot themselves be produced for sale, their commodification was necessarily fictitious, and consequently chronically unstable and thus frequently culturally destructive. Those three fictitious commodities respectively embodied no less than the literal habitation, the actual persons, and the essential lubricant necessary to any way of being -where households do not produce much of what they consume (Duncan 1996).

Polanyi raised the hackles of people across the ideological spectrum, and in a manner studiously impersonal but so unforgiving as to be unforgiven (Rothbard 2006a; Rothbard 2006b; Sievers 1968; Silver and Arrighi 2003). To the economistic liberals he said (and says): your model is a utopian dream incapable of realization, and to the extent you push for its full implementation, you will cause a self-protective response on behalf of society by at least some of its parts because of the ongoing, not just temporary, cultural destruction necessarily entailed by your utopian bullying. Because Polanyi documented that even the legislating architects of the markets model themselves saw the need repeatedly to pass other legislation tending in the opposite direction (to at least partly decommodify land, labour and money), there was no coherent response from the economistic liberal theorists. At their worst they resorted to conspiracy theory, seeing collectivists lurking everywhere, when really they should have looked first in their own mirrors (Hayek 1944).

As long as the Cold War was said to be the most important struggle, Polanyi's realism about the significance of culture had to be regarded as blasphemy by both the left and the right. With that absurdly dangerous conflict now behind us, some economists of the more moderate left and the more moderate right have decided to accept the cultural turn in social studies (Hodgson 2001). The very recent international 
financial farce of the late 2000s which has been the backdrop for recent geo-politics has substantially discredited those who remain obsessed with abstract models, if only because they utterly failed to predict the biggest threat to their own patch (Altvater 2009; Barth et al. 2008; Bremmer 2010; Claessens and Forbes 2001; Crotty 2003; Greenlaw et al. 2008; Kamstra et al. 2000; Semmler and Young 2010; Shin 2009; Wade 2008; Yellen 2009).

Karl Polanyi's analysis of deep and far-reaching modern economic disarray was published in England during World War Two using the phrase "The political and economic origins of our times" as the main title. On the west side of the Atlantic Ocean, that phrase served only as sub-title and the book was called The Great Transformation. That name stuck. The text has never been out of print, and has been translated into a great many languages (most recently Chinese, and Turkish), but in all cases with its Boston title (Polanyi 1957a). It is certainly a more arresting phrase than the longer one, but it has unfortunately facilitated no small amount of confusion. What Polanyi intended by the phrase was not the long and simultaneous experiments in industrialization and the various attempts to institute a self-regulating system of price-setting markets that started in England, and with which more than half of his monograph is concerned. Rather, in 1944 Polanyi used the phrase, "the great transformation," as is crystal clear in the second sentence of the book, to refer to the long subsequent process of social re-adjustment which was to start in earnest as soon as World War II was over. In the least developed and most challenging final part of the book he recommended that we, meaning, all of humanity, embark on this great transformation with our eyes open (Polanyi 1957a: 254). The point is to use the lessons of history properly analyzed to move decisively beyond the disastrous kinds of responses that marked the previous several decades, dominated as they were by wars, threats of war and the extremely powerful and alarming examples set by the fascist and command economy models.

Polanyi believed that industrialization was generally beneficial, and in any case more or less inevitable. However, he argued against basing public policy on formalist economic systems, stating that it was bound not just to lead to ongoing tensions, but in fact to deep disruptions of international trade (and consequent domestic economic upheaval as well, more or less everywhere). They are what made and make the fascist and Stalinist responses nothing to be remotely surprised about. Polanyi was equally critical of communist systems, and was vociferous in making this point during a fascinating exchange of letters with Arthur Koestler when the latter was in the throes of writing Yogi and the Commissar (Koestler 1945) (Polanyi’s Correspondence with Koestler, "Correspondence, 1898-1989." Karl Polanyi Archive, Karl Polanyi Institute of Political Economy, Montreal). His own idea of socialism was very different from that of the European communists of that period. For example, he wrote:

Socialism is, essentially, the tendency inherent in an industrial system to transcend the selfregulating market by consciously subordinating it to a democratic society. It is the solution natural to industrial workers who see no reason why production should not be regulated directly and why markets should be more than a useful but subordinate trait in a free society (Polanyi 1957a: 234).

Polanyi argued that the self-regulating market system actually invites state control, because such societies when pushed far in that direction inevitably self-protect by resorting to state power. So, writing in 1944, Polanyi said that as soon as the war against fascism is over, we must try to set up an orderly transformation in the way we regulate and stimulate economic activity, so as to avoid being subject to toxic political solutions. He made a strong case for a democratic mandate - to discuss at all levels, from the local to the global. He also made a case for enshrining some rights absolutely, whilst being pluralists institutionally. The political transformation Polanyi called for, he termed "great," but it is clear he did not have in mind a totalizing solution. The greatness would lie in its durable diversity of forms, and that this why his ideas resonate to this day. A truly great transformation would be made of literally millions of small components, complicatedly and sustainably linked in a myriad ways to others, and to natural processes at many levels.

Polanyi's text basically warns us the first half of the Twentieth Century was a horrible disaster caused by the insane duality of experiments embarked upon in the Nineteenth Century. It begins with the following statement: "Our thesis is that the idea of a self-adjusting market implied a stark utopia. Such an institution could not exist for any length of time without annihilating the human and natural substance of society; it would have physically destroyed man and transformed his surroundings into a wilderness." (Polanyi 1957a: 3). At that time arguably leaders could not know better, although critics such as William Cobbett and Robert Owen were quite certain at the outset that needless harm was being done, and said so, loudly and in print. But it certainly ought to follow that academics today should at least be made to rethink the status quo ante for a moment or two before rushing ahead with their commentary about the future. They despise the negative experiences of the last two centuries, but seem unable to escape their influence. Polanyi's deep transhistorical, non ethno-centric, pluralist approach ought to be liberating in this context.

It is these insights that form the basis of this collection. We build on Polanyi by urging that there is a remarkable general lesson for students of environment, technology, and society lurking in his approach to what happened in the century and a half before he wrote. The lesson is three-fold. Firstly, economies ought 
to be built on substantive foundations, and therefore, development must be a product of an inclusive consensus. It is crucial here that economic valuation be consensual in the broadest sense of the term. Thus we understand Polanyi's obsessive unfashionable argument that what he called "primitive" and "archaic" economies are relevant for contemporary industrial societies. These economies pointed us to forms of organization, characterized, for example by mutuality, reciprocity, and house-holding, which exemplified relationships of embedding that are available, at least as comforting allegories (Polanyi and Pearson 1977: 37).

Secondly, development, and economic processes more generally, ought to be embedded in ecological and material realities, and must reflect their societal and cultural contexts. For this reason, there must be multiple, plural, versions of development. People do not need a cookie cutter universal but rather a ubiquitous and yet non-standardized notion that can engender action. It is not to be concocted in a government bureaucracy, nor is it to be dreamed up in an NGO or a multi-lateral aid organization. Indeed, what must be universal is the embedding of economic and political institutions, such as markets and state bureaucracies, in community priorities. Thirdly, we need to be particularly cognizant about movements for habitation, because they serve as barometers, indicating the dis-embedding of economic activities from their cultural and ecological contexts.

\section{Our case studies}

The case studies in this volume are a product of collaborative work in co-author Rajan's graduate lab at UC Santa Cruz over the course of about half a decade, and later digested, refined and distilled at a workshop held in 2007 at the School of Advanced Research in the Human Experience in Santa Fe, New Mexico. Our first case, by Roopali Phadke, is a discussion of a movement to build a small dam in Western India (Phadke 2013). Against the backdrop of five decades of frenzy in large dam building, a rural community came into being (united despite differences in caste and class) and forged an alliance with engineers and retired bureaucrats. In doing so, it helped dream up an alternative way not only to harvest water and irrigate fields, but to re-imagine and re-define food and water security, crop diversity and increased tree cover. This case is representative of many in India and around the world and in sectors ranging from forestry to water, involving community-based environmental governance. It also helped deliver a strong political statement - that village communities can drive technical development, through their experiential knowledge and self-determined needs.

Next, we move to Nicaragua, and to a case involving the development of sustainable coffee networks. This case study is representative of many attempts to build alternative commodity systems that aim to render the production process ecologically sustainable, and the distribution process more equitable. In the words of author Chris Bacon:

I am interested in innovations that could enable community level empowerment, equity and more sustainability livelihoods. Beyond the vital role of highlighting systematic traps and shortcomings associated with the corporatization of proposed alternatives, uncovering histories of violence and displacement, and identifying avenues for policy change, if connected to participatory action research with and for communities and social movements, there is a strand of political ecology that can contribute to both opening ecological imaginations and creating possibilities through collective action and sustainability innovations. (Bacon 2013: 103)

Our third case study is from El Salvador, and is about how a community recovering from sustained conflict and its concomitant environmental re-wilding actually envisioned environmental governance and provided an alternative to government and international multi-lateral aid efforts at land redistribution and land use changes. This case, by Ariane de Bremond, is representative of both community driven approaches to resource use, as well as being an example of post-war agrarian policy (de Bremond 2013).

From Latin America, we then move to California in the United States. Our first stop is the city of Davis in California, with a case study by Ben Weil that examines attempts at creating more livable urban spaces in the city (Weil 2013). Although Davis is an affluent bubble in the first world, the lessons from there are relevant to several on-going efforts around the world to actualize new green urban utopias. Last but by no means least, the second Californian case study is about social movements to ban genetically engineered modified rice and fish. This case study is simultaneously about community driven efforts to protect themselves from the ecological risks associated with genetically engineered crops, as well as to widen the discussion about food security, and as such, it resonates with several similar efforts around the world. This case is, in effect, a set of stories about people trying to maintain culture in a particular place by acting in that place. Interestingly, they end up creating wider eddies, if not waves. The authors, Dustin Mulvaney and Anna Zivian, argue that: 
California's governance of GE salmon and GE rice can be considered successes insofar as they show states' capacity to regulate the release of particularly risky GEOs. California's interventions give activists and scientists more time to evaluate the consequences of such releases. These policies also fill perceived regulatory voids, adopting a precautionary policy in the face of uncertainty about federal rules. ........

But perhaps where anti-GE actions offer the most hope is outside the formal risk policy arena. Anti-GE activism is also changing the trajectory of agricultural research both inside genetic engineering practices, as, for example, with open source biotechnology, and outside them, by advocating local food sheds and sustainable agriculture on agro-ecological principles. These are reactions to existing trends and paradigms, much as Polanyi might anticipate. While activists seek to regulate industrial agriculture and its attendant risks, they also promote alternative paradigms. The seeds that anti-GE activists sow in resistance to GEOs take root as precautionary policies as they open and occupy new spaces for alternatives. (Mulvaney and Zivian 2013:174 and 175)

Collectively, these case studies resonate together with a Polanyian approach to political ecology. Virtually all the cases exemplify the concept of a substantive economy and the idea of embeddedness, with an emphasis on how various social and ecological factors get embedded within specific social, cultural and ecological contexts. Phadke, Bacon, de Bremond, and Weil specifically address questions such as: what are the values that underly the design of respectively economic or technological systems? How is equity defined? And how are democracy and plurality addressed? Again, Mulvaney and Zivian, and indeed most of the other studies, exemplify double movements aiming at "habitation" - the forging of what we call ecologies of hope. These struggles, which in themselves might not make for fundamental or structural change, do enable a slightly more livable world, contributing pieces toward a great transformation.

In each of the case studies to follow, communities simply and normally do what they can unless prevented, and afterwards they neither feel they have accomplished nothing, nor feel they have changed the world for once and for all. Modest hopes for actions that can make some considerable difference is the whole point here, and it is not a trivial one. So the level of analysis here is not the state. It is not the region or subregion for those terms are also too comprehensive, and too "geographical." It is also not just "the local" we are considering. We are discussing phenomena that are felt always at many levels, but differently at each one, and that, depending on position in the chain of preconditions and outcomes, carry radically uneven quanta of significance, importance, consequence, magnitude, whatever you want to call it. The point is to look and to see, and to think, and to compare, and then to try to spread what can be shared, at whatever levels might hold promise.

All of these cases are of self-organized communities thinking and acting very contextually and specifically. Despite considerable differences in context - for example, in class and regional backgrounds, and in political ideologies and strategic objectives, the five cases represent attempts, by groups of people around the world, to focus on the here and the now, and in so doing, to carve out niches for survival, where prospects otherwise might have been bleak, or to extend new paths for social betterment. We call these new niches and pathways ecologies of hope - referring people to everyday initiatives, around the world, that do not make revolutionary claims, but which in small but significant ways, help transform the lives of people and communities.

It is important to note that the case studies in this special issue are not more examples of subaltern studies. As such, terms such as class, margins, center, and periphery, do not have much salience in our analysis. There are problems for which these terms are appropriate, but every so often they subtly mislead (and sometimes not so subtly). We are simply trying to focus without analytic prejudice on important, but not necessarily dramatic or even dominant aspects of what is actually everyday life for the people we have studied. So, to be sure, some of the issues are sub-national but not one whit less important in terms of political resonance. For example, for households heavily reliant on selling most of the coffee they grow, a change in world commodity prices may be very serious, but that in itself does not mean these producers are or were normally super-exploited or ignored, or hugely vulnerable or helpless. Neither does a growing problem in their sector mean the whole of whatever wider or national economy they live in is going to collapse. It's not quite automatic at that scale, however serious the immediate impacts. It is a problem unlikely to command widespread attention from outside, but it is a problem that needs a solution, one that is scaled to the locally practical scale of possibilities and one that can be implemented soon. Our point is that often people do have options at their own level which they can operationalize and which can definitely help them. It is true that these smaller-scale solutions are normally unlikely to issue in generally transformative rearrangements of the institutional "fundamentals" for their sector, but, they show us that, at the "middle," people have learned not to trust such alterations as permanent either.

In presenting these case studies, we invite scholars of science, technology and society, and of political ecology, not just to recognize the existence of the sheer effervescence of movements of habitation at the nethers the world over, but to re-think the politics of their own scholarship. The cases we present offer 
modest starts in this regard. Phadke points to the role scholars can play in designing new socio-technological systems. Bacon shows how crypto-Polanyian political ecologists can help create new embedded markets. De Bremond's analysis can be the point of departure for political ecologists who can translate the key lessons from her case to other regions of the world. The same can be said for the cases described by Weil, and Mulvaney and Zivian. Thus, while engagement, deconstruction, and social mobilization - the essential verities in the scholarly genre in political ecology - and the visible specter of structural transformation they offer, are laudable goals, we argue for the recognition of the potential of less structural and scalable interventions. Creating spaces for habitation, and carving out ecologies of hope, might not mitigate catastrophic global change or miraculously transform the unjust into the just, but may help make life and livelihoods a bit more habitable. For people whose lives are affected, this matters.

\section{Ecologies of Hope, edited by S. Ravi Rajan and Colin A.M. Duncan}

1. S. Ravi Rajan and Colin Duncan: Ecologies of Hope: environment, technology and habitation - case studies from the intervenient middle.

2. Roopali Phadke: Water works in India.

3. Christopher Bacon: Quality revolutions, solidarity networks, and sustainability innovations: following Fair Trade coffee from Nicaragua to California.

4. Ariane de Bremond: Regenerating conflicted landscapes in post-war El Salvador: livelihoods, land policy, and land use change in the Cinquera Forest.

5. Benjamin Weil: Solar city, bike city, growth city: governance and energy in Davis, California.

6. Dustin Mulvaney and Anna Zivian: Sowing seeds of hope in California's fields of resistance to Pharm rice and Frankenfish.

\section{References}

Altvater, E. 2009. Postneoliberalism or postcapitalism? The failure of neoliberalism in the financial market crisis. Development Dialogue 51: 73-86.

Aristotle. 1999. Nicomachean ethics. 2nd ed. Cambridge: Hackett Publishing Co.

Bacon, C.M. 2013. Quality revolutions, solidarity networks, and sustainability innovations: following Fair Trade coffee from Nicaragua to California. Journal of Political Ecology 20: 98-115.

Barth, J., T. Li, T. Phumiwasana, and G. Yago. 2008. A short history of the subprime mortgage market meltdown. GH Bank Housing Journal 2 (2): 2-8.

Beckert, J. 2007. The great transformation of embeddedness: Karl Polanyi and the new economic sociology. Cologne: Max Planck Institute for the Study of Societies.

Benítez, F. 2011. Occupy Wall Street. Ediciones ARQ 79.

Birchfield, V. 1999. Contesting the hegemony of market ideology: Gramsci's 'good sense' and Polanyi's double movement. Review of International Political Economy 6 (1): 27-54.

Bremmer, I. 2010. The end of the free market: who wins the war between states and corporations? European View 9 (2): 249-252.

Castells, M. 1985. The city and the grassroots: a cross-cultural theory of urban social movements. Berkeley: University of California Press.

Claessens, S. and K. Forbes (eds.). 2001. International financial contagion. Kluwer Academic Publishers.

Clark, B. and J.B. Foster. 2001. William Stanley Jevons and the coal question: an introduction to Jevons's "Of the Economy of Fuel". Organization and Environment 14 (1): 93-98.

Cozzens, S.E. and E. J. Woodhouse. 1995. Science, government, and the politics of knowledge. In S. Jasanoff, G. Markle, J. C. Petersen and T. Pinch (eds.) Handbook of Science and Technology Studies. Thousand Oaks: Sage. Pp. 533-553.

Crotty, J. 2003. The neoliberal paradox: the impact of destructive product market competition and impatient finance on nonfinancial corporations in the neoliberal era. Review of Radical Political Economics 35 (3): 271-79.

Dalton G. (ed.).1968. Primitive, archaic, and modern economies: essays of Karl Polanyi. New York: Doubleday.

Danaher, K. (ed.) 1994. 50 years is enough: The case against the World Bank and the International Monetary Fund. Cambridge: South End Press.

De Bremond, A. 2013. Regenerating conflicted landscapes in post-war El Salvador: livelihoods, land policy, and land use change in the Cinquera Forest. Journal of Political Ecology 20: 116-136.

della Porta, D. and M. Diani. 2006. Social movements: an introduction. Oxford: Wiley-Blackwell. 
Duncan, C.A.M. 1996. The centrality of agriculture: between humankind and the rest of nature. Montreal: McGill-Queens University Press.

Escobar, A. 1984. Discourse and power in development: Michel Foucault and the relevance of his work to the Third World. Alternatives 10 (3): 377-400.

Gill, S. 1995. Theorizing the interregnum: the double movement and global politics in the 1990s. In B. Hettne (ed.) International political economy: understanding global disorder. London: Zed. Pp. 65-99.

Gorz, A. 1968. Reform and revolution. Socialist Register 5: 111-143.

Greenlaw, D., J. Hatzius, A.K. Kashyap and H.S. Shin. 2008. Leveraged losses: lessons from the mortgage market meltdown. U.S. Monetary Policy Forum Report No. 2. Chicago: University of Chicago Graduate School of Business.

Habermas, J. 1981. New social movements. Telos 49: 33-37.

Hackett, E.J., O. Amsterdamska, M. Lynch and J. Wajcman. 2008. The handbook of science and technology studies. $3^{\text {rd }}$ Ed. Cambridge: MIT Press.

Harvey, D. 1996. Justice, nature and the geography of difference. Malden: Blackwell Publishers.

Hayek, F.A. 1944. The road to serfdom. London: Routledge.

Hettne, B. 1997. The double movement: global market versus regionalism. In R.W. Cox (ed.) The new realism: perspectives on multilateralism and world order. Tokyo: United Nations University Press. Pp. 223-244.

Hodgson, G. M. 2001. How economics forgot history: the problem of historical specificity in social science. 1st Ed. London: Routledge.

Hoskins, W.G. 1953. The rebuilding of rural England, 1570-1640. Past and Present 4: 44-59.

Hoskins, W.G. 1957. The Midland peasant: the economic and social history of a Leicestershire village. London: Macmillan and Co.

Hoskins, W.G. 1964. Harvest fluctuations and English economic history, 1480-1619. The Agricultural History Review 12 (1): 28-46.

Hoskins, W.G. 1969. The making of the English landscape. Leicester: Penguin Books.

Hoskins, W.G. 1976. The age of plunder: the England of Henry VIII, 1500-1547. London and New York: Longman.

Hoskins, W.G. and L.D. Stamp. 1963. The common lands of England and Wales. Vol. 45. London: Collins.

Jevons, W.S. 1906. The coal question: an inquiry concerning the progress of the nation, and the probable exhaustion of our coal-mines. London: Macmillan.

Kamstra, M.J., L.A. Kramer, and M.D. Levi. 2000. Losing sleep at the market: the daylight saving anomaly. The American Economic Review 90 (4): 1005-1011.

Koestler, A. 1945. The Yogi and the Commissar and other essays. London: Macmillan.

Mulvaney, D. and A. Zivian. 2013. Sowing seeds of hope in California's fields of resistance to Pharm rice and Frankenfish. Journal of Political Ecology 20:159-179.

Naipaul, V.S. 1990. India: a million mutinies now. New York: Penguin. Reprint 2011, Vintage Books.

O'Brien, R. 2000. Contesting global governance: multilateral economic institutions and global social movements. Cambridge: Cambridge University Press.

Peet, R., and M.J. Watts (eds.) 2004. Liberation ecologies: environment, development, social movements. $2^{\text {nd }}$ ed. London: Routledge.

Phadke, R. 2013. Water works in India. Journal of Political Ecology 20: 80-97.

Polanyi, K. 1935. The essence of fascism. In J. Lewis (ed.) Christianity and the social revolution. Hallandale: New World Book Manufacturing Co., Inc. Pp. 359-94.

Polanyi, K. 1947. Our obsolete market mentality. In G. Dalton (ed.) 1968. Primitive, archaic, and modern economies: essays of Karl Polanyi. New York: Doubleday. Pp. 59-77.

Polanyi, K. 1957a [1944]. The Great Transformation. Vol. 2. Foreword by Robert MacIver. Boston: Beacon Press.

Polanyi, K. 1957b. Aristotle discovers the economy. In K. Polanyi, C.M. Arensberg and H.W. Pearson (eds.) Trade and market in the early empires. Chicago: Regnery. Pp. 64-94.

Polanyi, K. 1957c. The economy as instituted process. In K. Polanyi, C.M. Arensberg and H.W. Pearson (eds.) Trade and market in the early empires. Chicago: Regnery. Pp. 243-270.

Polanyi, K. 1968. The semantics of money-uses. In G. Dalton (ed.) Primitive, archaic and modern economies: essays of Karl Polanyi. New York: Doubleday. Pp. 175-203.

Polanyi, K., C.M. Arensberg, and H.W. Pearson. 1957. Trade and market in the early empires. New York: Free Press.

Polanyi, K. and H.W. Pearson. 1977. The livelihood of man (studies in social discontinuity). New York: Academic Press. 
Prahalad, C.K. 2010. The fortune at the bottom of the pyramid: eradicating poverty through profits. Philadelphia: Wharton School Publishing.

Rabinow, P., and N. Rose. 2006. Biopower today. BioSocieties 1 (2): 195-217.

Rich, B. 1994. World Bank/IMF: 50 years is enough. In K. Danaher (ed.) 50 years is enough: the case against the World Bank and the International Monetary Fund. Cambridge: South End Press.

Rothbard, M.N. 2006a. An Austrian perspective on the history of economic thought. Alabama: Ludwig von Mises Institute.

Rothbard, M.N. 2006b. For a new liberty: the libertarian manifesto. Alabama: Ludwig von Mises Institute.

Semmler, W. and B. Young. 2010. Lost in temptation of risk: financial market liberalization, financial market meltdown and regulatory reforms. Comparative European Politics 8 (3): 327-353.

Shin, H.S. 2009. Securitisation and financial stability. The Economic Journal 119 (536): 309-332.

Sievers, A. M. 1968. Has market capitalism collapsed? A critique of Karl Polanyi's new economics. Studies in History, Economics, and Public Law, No. 553. AMS Press.

Silver, B.J., and G. Arrighi. 2003. Polanyi's "double movement": the belle epoques of British and US hegemony compared. Politics and Society 31 (2): 325-355.

Skidelski, R. 2003. John Maynard Keynes 1883-1946: economist, philosopher, statesman. London: Penguin.

Wade, R. 2008. Financial regime change. New Left Review 53 (5): 5-21.

Weil, B. 2013. Solar city, bike city, growth city: governance and energy in Davis, California. Journal of Political Ecology 20: 137-158.

Wignaraja, P. 1993. New social movements in the South: empowering the people. London: Zed Books.

Yellen, J. 2009. A Minsky meltdown: lessons for central bankers. Paper read at Speech at the 18th Annual Hyman P. Minsky Conference. New York.

\begin{abstract}
This paper is an introduction to a special issue of the Journal of Political Ecology on "Ecologies of Hope." The authors argue that discrete, specific, and often, local actions can create spaces that are bettering human lives and livelihoods. The five papers identify actions and movements that are situated in the "middle" between the individual and larger social and economic formations, and inbetween social and economic status- quo and revolution. They are everyday initiatives that do not make revolutionary claims, but which in small but significant ways, help transform the lives of people and communities. These "ecologies of hope" resonate with the work of Karl Polanyi, and his identification of the modern disembedding of the economy and the environment from its societal and cultural context. Polanyi argued that processes that result in a loss of cultural "habitation" engender movements by societies to protect their social solidarity, and distortions of their relationship with the natural environment. Creating and carving out "ecologies of hope" may not mitigate catastrophic global change or miraculously transform the unjust into the just, but does make life and livelihoods a bit more habitable. For people whose lives are affected, this matters. Political ecology should recognize the importance of creating spaces for "habitation" that are not necessarily structural and scalable.
\end{abstract}

Key words: Karl Polanyi, ecologies of hope, habitation, self-organized communities. 


\section{Resumé}

Ce document est une introduction à un numéro spécial du Journal of Political Ecology sur «écologies de l'espoir». Les auteurs soutiennent que les actions qui sont discrets, spécifiques et locales peuvent créer des espaces qui font une vie meilleure, et de meilleurs moyens de subsistance. Les cinq articles identifier les actions et les mouvements sociaux qui se trouvent en «milieu» entre l'individu et les grandes formations sociales et économiques, et entre statu-quo et de la révolution. Ce sont des initiatives quotidiennes qui ne font pas prétentions révolutionnaires, mais qui dans de petits moyens, aider à transformer la vie des personnes et des communautés. Ces «écologies de l'espoir» sont en accord avec les travaux de Karl Polanyi, et son identification du déracinement moderne de l'économie et de l'environnement de son contexte social et culturel. Polanyi a fait valoir que les processus qui conduisent à la perte de l'«habitation» culturelle créer des mouvements pour protéger la solidarité sociale, et de créer de meilleures relations avec l'environnement naturel. La création de «écologies de l'espoir» ne peut atténuer le changement global catastrophique, ou miraculeusement transformer l'injustice, mais elle rend la vie et les moyens d'existence un peu plus «habitable». Pour les personnes dont la vie est touchée, cela est important. L'écologie politique devrait reconnaître l'importance de créer des espaces pour «habitation» qui ne sont pas nécessairement structurale et extensible.

Mots clés: Karl Polanyi, écologies de l'espoir, habitation, communautés auto-organisées.

\section{Resumen}

Este artículo es una introducción a una edición especial del Journal of Political Ecology sobre "Ecologías y esperanza". Los autores argumentan que actuaciones independientes, específicas y a menudo locales pueden crear espacios que están mejorando vidas humanas y medios de susbsistencia. Los cinco artículos identifican acciones y movimientos que se sitúan en el "medio" entre las formaciones sociales y económicas individuales y de mayor tamaño, y entre el status quo y la revolución social y económica. Son iniciativas cotidianas que no suponen una revolución, pero que de manera modesta pero significativa, ayudan a transformar las vidas de personas y comunidades. Estas "ecologías de esperanza" tienen conexiones con el trabajo de Karl Polanyi, y su identificación de la desincrustación moderna de la economía y el medio ambiente de su contexto social y cultural. Polanyi arguía que los procesos que resultan en pérdida de "habitación" cultural engendran movimientos en sociedades para proteger su solidaridad social y las distorsiones de su relación con el medioambiente natural. Crear y forjar "ecologías de esperanza" puede no mitigar un cambio global catastrófico o transformar milagrosamente lo injusto en justo, pero al menos hacen la vida y el sustento un poco más habitables. Para las personas cuyas vidas resultan afectadas, esto es importante. La ecología política debería reconocer la importancia de crear espacios para la habitación que no son necesariamente estructurales y medibles.

Palabras clave: Karl Polanyi, ecologías de esperanza, habitación, comunidades auto-organizadas. 